\title{
The Relationship Between Insulin Resistance and Serum Preptin Level
}

\author{
Serum Preptin Düzeyi ve İnsülin Direnci Arasındaki İlişki
}

\author{
Sengül Aydın Yoldemir ${ }^{1}$, Özgür Altun $^{1}$
}

${ }^{1}$ University of Health Sciences, Okmeydan1 TRH, Department of Internal Medicine

\begin{abstract}
Objectives: Preptin is derived from e-peptide of proinsulin-like growth factor II, is present in islet $\beta$-cell granules and is co-secreted with insulin in response to glucose. Studies have suggested that preptin plays a role in glucose and lipid metabolism. In this study, we have investigated the serum preptin levels in patient with insulin resistance (IR) and by this way, we aimed to define the role of preptin as a parameter in early diagnosis and monitoring progression of diabetes.

Materials and Methods: The study included 49 IR patients and 37 healthy controls. The presence of IR was based on the Homeostatic model of assessment- insulin resistance (HOMA-IR) level of 2.7 or higher. Fasting plasma samples were obtained from the patients and the control group. The serum levels of preptin were measured with an Enzyme-Linked Immuno Sorbent Assay (ELISA)kit.

Results: The IR patients had higher fasting insulin, HOMA-IR and triglyceride levels than the control subjects $(\mathrm{p}<0.01)$. And the serum levels of preptin were significantly higher in IR patients than in the healthy controls $(492.00 \pm 289.23$ and $98.41 \pm 50.64$ respectively; $\mathrm{p}<0.01)$. They showed a positive correlation with the HOMA-IR $(\mathrm{r}=0.43 ; \mathrm{p}<0.01)$, the fasting insulin level $(\mathrm{r}=0.64 ; \mathrm{p}<0.001)$, body mass index count $(\mathrm{r}=0.41 ; \mathrm{p}<0.01)$ and triglyceride level $(\mathrm{r}=0.26 ; \mathrm{p}<0.05)$.

Conclusion: The serum preptin level was higher in patients with IR. These findings demonstrate that there is a potential link between preptin and glucose-lipid metabolism. In conclusion, high preptin levels in patients with insulin resistance suggest that preptin may play a role in the pathogenesis of insulin resistance.
\end{abstract}

Keywords: Preptin, insulin resistance, obesity

$\ddot{\mathrm{O} z}$

Giriş: Preptin, proinsülin benzeri büyüme faktörü-II'nin e-peptidinden türetilir. Adacık $\beta$ hücre grenüllerinde bulunur ve glikoza yanıt olarak insülin ile birlikte salgılanır. Daha önce yapılan çalışmalarda, preptinin glikoz ve lipid metabolizmasında rol oynadığını öne sürülmüştür. Bu çalışmada, insülin direncine (IR) sahip hastalarda serum preptin düzeylerini araştırdık ve bu şekilde preptinin diyabetin erken teşhisinde ve izlenmesinde parametre olarak rolünü tanımlamayı amaçladık.

Materyal ve Metot: Çalışmaya 49 IR hastası ve 37 sağlıklı kontrol alındı. IR varlığ1, Homeostatik değerlendirme-insülin direnci (HOMA-IR) 2,7 veya daha yüksek seviyede olması ile belirlendi. Hastalardan ve kontrol grubundan açlık plazma örnekleri alındı. Serum preptin seviyeleri, bir Enzime Bağlı İmmün Sorbent Testi (ELISA) kiti ile ölçüldü.

Bulgular: IR hastaları kontrol grubundan daha yüksek açlık insülin, HOMA-IR ve trigliserit düzeylerine sahipti ( $p<0,01)$. Serum preptin düzeyleri IR hastalarında sağlıklı kontrollere göre anlamlı derecede

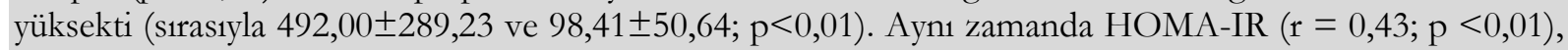
açlı insülin düzeyi $(r=0,64 ; p<0,001)$, vücut kitle indeksi $(r=0,41 ; p<0,01)$ ve trigliserid düzeyi $(r=0,26$; $\mathrm{p}<0,05$ ile pozitif korelasyon gösterdi.

Sonuç: Serum preptin düzeyi IR'li hastalarda daha yüksekti. Bu bulgular preptin ve glukoz-lipid metabolizması arasında potansiyel bir bağlantı olduğunu göstermektedir. Sonuç olarak, insülin direncine sahip hastalarda yüksek preptin seviyeleri, preptinin insülin direncinin patogenezinde rol oynayabileceğini düşündürmektedir.

Anahtar Kelimeler: Preptin, insulin rezistans1, obezite

\section{Yazışma Adresi / Correspondence:}

Şengül Aydın Yoldemir

e-mail: sengulaydinn@gmail.com

Date of submission: 30.06.2019

Date of admission: 23.10.2019 


\section{Introduction}

The global epidemic of overweight and obesity is escalating and has become a major health challenge. Obesity is implicated as a cause of many devastating diseases, including diabetes, cardiovascular disorders, and cancers. ${ }^{1}$ The association of obesity with type 2 diabetes has been recognized for decades, and the major basis for this link is the ability of obesity to engender insulin resistance (IR). IR is a fundamental aspect of the etiology of type 2 diabetes and is also linked to a wide array of other pathophysiologic sequelae including hypertension, hyperlipidemia, atherosclerosis (i.e., the metabolic syndrome, or syndrome $\mathrm{X}$ ), and polycystic ovarian disease. ${ }^{2} \mathrm{In}$ recent studies, new biomarkers associated with the diagnosis, follow-up and progression of diabetes gained more importance.

Pancreatic islet $\beta$-cells play a major regulatory role in physiology, mainly through their secretion of insulin, a peptide hormone that exerts profound effects on metabolism. ${ }^{3}$ Recent studies ${ }^{4-6}$ have revealed that insulin is not the only metabolically important hormone stored in and secreted from the $\beta$-cell granule. ${ }^{3}$

Preptin is derived from e-peptide of proinsulin-like growth factor II(pro-IGF-II), is present in islet $\beta$-cell granules and is co-secreted with insulin in response glucose and which increases glucose-mediated insulin secretion. ${ }^{3-7}$ Preptin is a 34-residue polypeptide first isolated from the mouse pancreatic b-cell line bTC6-F7 by Bucham and colleagues in $2011 .^{3}$ Studies have positively correlated elevated preptin levels in patients with metabolic disturbances including gestational diabetes mellitus, polycystic ovary syndrome, type 2 diabetes mellitus and impaired glucose tolerance. ${ }^{8}$ Preptin has been found to elevate insulin secretion. ${ }^{9}$ Preptin is cleaved by endogenous proteases at phenylalanine 21 and has a half-life of 5 min in vivo. ${ }^{8}$

Preptin is believed to be a physiological enhancer of insulin secretion induced by glucose. ${ }^{9}$ There is a strong correlation between obesity and hyperinsulinemia and IR. ${ }^{10}$ Therefore, the relationship between IR and preptin levels would be worth investigation. To the best of our knowledge, there is not any study in literature about the association of serum preptin levels and IR. In this study, we have investigated the serum preptin levels in patient with IR and by this way we aimed to define the role of preptin as a parameter in early diagnosis and monitoring progression of diabetes.

\section{Materials and Methods}

\section{Patient Selection}

This cross-sectional study was performed at internal medicine clinic, Istanbul, Turkey. It included 49 patients (14 male and 35 female) who were diagnosed as having IR, and an age- and sexmatched control group of 37 (8 male and 29 female) individuals who had similar baseline characteristics. The presence of IR was based on HOMA-IR level of 2,7 or higher. Of the 49 patients with insulin resistance, 23 of them had with normal glucose tolerance (NGT) and 28 of them had impaired glucose tolerance (IGT). Control group had normal insulin level and NGT. We also described the patients in 3 different subgroups. Group 1; patients with normal insulin level and NGT, group 2; patients with IR and NGT, group 3; patients with IR and IGT. Patients with normal insulin level and NGT, had no family history of T2DM, no clinical evidence of major disease, and were recruited from an unselected population who had undergone routine medical check-ups. The diagnosis of IGT was based on oral glucose tolerance tests and World Health Organization criteria ${ }^{11}$. Patients with IGT and IR were newly diagnosed and had not been treated with oral antihyperglycemic agents. None of control subjects were taking any medication known to alter glucose tolerance.

Exclusion criteria were the presence of systemic disease, inflammatory and infectious diseases and malignancies. Informed written consent was obtained from all the participants (patients and controls) after receiving a full explanation about the study and its purpose. 
The study protocol was approved by Hospital ethics committee, Istanbul (date: 10.10.2017 no: 732). Informed written consent was obtained from all the participants (patients and controls) after receiving a full explanation about the study and its purpose.

\section{Measurements}

Body mass index (BMI) was obtained using the formula weight $(\mathrm{kg}) /$ height $(\mathrm{m})^{2}$. Obesity was defined as a BMI $>30 \mathrm{~kg} / \mathrm{m}^{2}$. Blood samples were obtained after overnight fasting. Serum cholesterol, triglyceride, high-density lipoprotein cholesterol (HDL-C), glucose, creatinine, and urea were measured by enzymatic colorimetric methods with commercially available kits (COBAS-8000, Roche Diagnostics GmbH, Mannheim, Germany), and low-density lipoprotein cholesterol C (LDL-C) was calculated according to the Friedewald formula. Blood HbA1c was determined by high-performance liquid chromatography method with commercially available kits (Premier Hb9210, Trinity Biotech, A.B.D.). Final results were expressed as percent HbA1c of the total Hemoglobin according to the protocol of the Diabetes Control and Complications Trial/National Glycohemoglobin Standardization Program (DCCT/NGSP). The insulin level was determined by electro chemi luminescence immunoassay method with commercially available kits (COBAS-8000, Roche Diagnostics, Mannheim, Germany). IR was estimated via the HOMAIR. HOMA-IR were calculated from fasting glucose levels with the following equations: HOMA$\mathrm{IR}=$ insulin $(\mathrm{uIU} / \mathrm{mL}) \times$ glucose $(\mathrm{mg} / \mathrm{dL}) / 405$. Plasma was collected and kept at $-80 \mathrm{C}$ until assayed. Serum preptin levels were studied using a Human

Preptin kit (catalog no: CK-E10788) by the enzyme-linked immunosorbent assay (ELISA) method. The analytical (linear) detection range was $62.50-4000 \mathrm{pg} / \mathrm{mL}$, the minimal detection limit was $37.50 \mathrm{pg} / \mathrm{mL}$, the reported intraassay and interassay CV's were $5.62 \%$ and $6.99 \%$, respectively for preptin assay kit.

\section{Statistical Analysis}

SPSS version 12.0 was used for statistical analyses descriptive statistical methods (mean, standard deviation, frequency, ratio, minimum, maximum) were used to evaluate the study data. The data obtained in the study were expressed as the mean \pm SD. Student's t-test, Pearson Correlation Test were used for normally distributed quantitative parameters. If the data were not normal distributed, it would be correct to turn to non-parametric tests such as Mann-Whitney-U and Sperman. Independent Samples t-test was used to detect the differences among the groups. Spearman's correlation coefficients were employed for bivariate associations of preptin and other covariates. Values of $\mathrm{p}<0.05, \mathrm{p}<0.01$, and $\mathrm{p}<0.001$ were accepted as statistically significant.

\section{Results}

\section{Clinical characteristics of the study subjects}

The clinical characteristics of our subjects are shown in Table1. There were no significant differences in the age, BMI, fasting glucose, total cholesterol, HDL-C, LDL-C, urea, creatinine and $\mathrm{HbA1c}$ levels between the patients with IR and control subjects. The IR patients had a significantly higher fasting insulin, HOMA-IR and triglyceride levels than the control subjects $(p<0.001)$. There were no significant differences between male and female subjects in plasma preptin levels.

The clinical characteristic of our subgroups are shown in Table 2. Serum HOMA-IR and insulin levels in IR and NGT group higher than IR (-) and NGT group (control group), as expected. Serum HOMA-IR and insulin levels in IR and IGT group were found as significantly higher than the control group $(\mathrm{p}<0.001)$.

\section{Relationships between serum preptin level and other variables}


The serum preptin levels showed a positive correlation with HOMA-IR (rho $=0.43 ; \mathrm{p}=0.006$ ), fasting insulin (rho $=0.64 ; \mathrm{p}=0.001), \mathrm{BMI}(\mathrm{rho}=0.41 ; \mathrm{p}=0.003)$ and triglyceride (rho $=$ $0.26 ; \mathrm{p}=0.014)$ in patients with IR as shown in Table 3 (Figure 1).

(a)

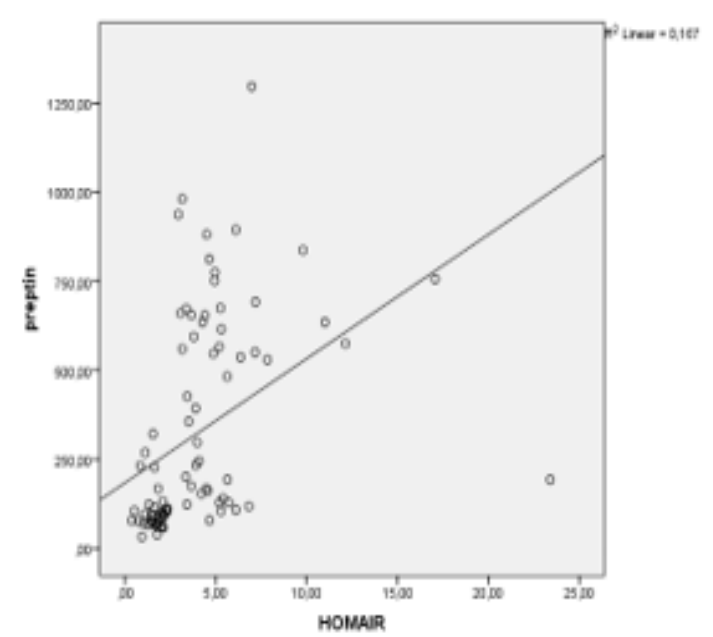

(c)

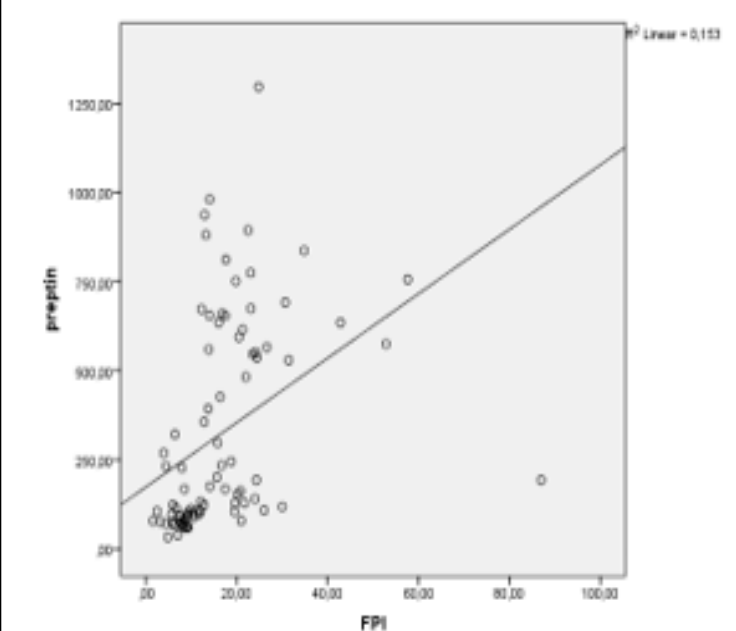

(b)

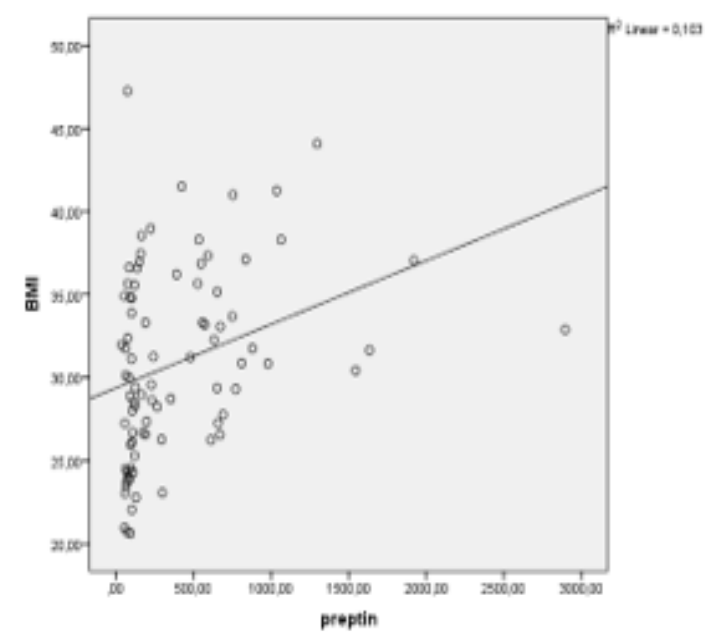

(d)

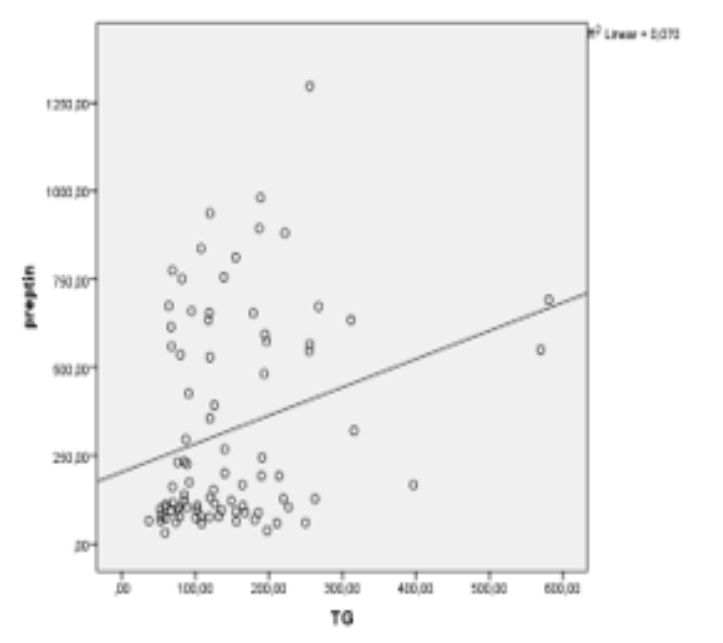

Figure 1. Spearman's rank correlation analysis of preptin and a) HOMA-IR $(r=0.43 ; p<0.01)$, b) BMI $(r=0,41 ; p<0,01), \mathrm{c})$ FPI $(r=0,64 ; p<0,001), \mathrm{d}) \operatorname{Tg}(r=0,26 ; p<0,05)$

\section{Serum preptin levels of patients}

The serum preptin levels were significantly higher in the patients with IR compared to the healthy controls $(\mathrm{p}<0.01)$ (Table 1$)$.

The serum preptin levels were significantly higher in the IR with NGT patients and IR with IGT patients compared to the healthy controls $(423.41 \pm 285.23 \mathrm{pg} / \mathrm{mL}, 543.34 \pm 295.62 \mathrm{pg} / \mathrm{mL}$ and $104.97 \pm 62.22 \mathrm{pg} / \mathrm{mL} ; \mathrm{p}<0.01: \mathrm{p}<0.05)$. There was no significant difference in mean serum preptin levels between IR with NGT and IR with IGT (Table 2). 
Table 1. Clinical characteristics and preptin levels of patients and control group

\begin{tabular}{|c|c|c|c|}
\hline & $\begin{array}{c}\text { With insulin resistance } \\
(\text { HOMA-IR }>2.7) \mathrm{n}=49 \\
\text { Mean } \pm \text { s.d. }\end{array}$ & $\begin{array}{c}\text { Control group } \\
\text { (HOMA-IR<2.7) } \\
\text { n=37 } \\
\text { Mean } \pm \text { s.d. }\end{array}$ & $\mathrm{p}$ \\
\hline Age (years) & $47.80 \pm 11.60$ & $39.50 \pm 11.10$ & 0.68 \\
\hline $\mathrm{BMI}\left(\mathrm{kg} / \mathrm{m}^{2}\right)$ & $32.72 \pm 4.63$ & $28.44 \pm 6.12$ & 0.08 \\
\hline Preptin (pg/mL) & $492.00 \pm 289.23$ & $98.41 \pm 50.64$ & $0.001 * *$ \\
\hline FPG $(\mathrm{mg} / \mathrm{dL})$ & $99.93 \pm 12.68$ & $87.7 \pm 9.59$ & 0.06 \\
\hline $\mathrm{FI}(\mu \mathrm{U} / \mathrm{mL})$ & $22.98 \pm 13.21$ & $7.92 \pm 3.44$ & $<0.001 * * *$ \\
\hline Total cholesterol (mg/dL) & $197.72 \pm 47.33$ & $188.64 \pm 35.62$ & 0.14 \\
\hline HDL-C (mg/dL) & $43.81 \pm 10.64$ & $49.92 \pm 10.42$ & 0.97 \\
\hline LDL-C (mg/dL) & $123.02 \pm 43.00$ & $108.01 \pm 39.61$ & 0.64 \\
\hline Triglyceride (mg/dL) & $170.93 \pm 112.71$ & $114.00 \pm 54.72$ & $0.002 * *$ \\
\hline Urea $(\mathrm{mg} / \mathrm{dL})$ & $26.31 \pm 7.52$ & $22.21 \pm 6.59$ & 0.40 \\
\hline Creatinin $(\mathrm{mg} / \mathrm{dL})$ & $0.77 \pm 0.22$ & $0.70 \pm 0.21$ & 0.93 \\
\hline $\operatorname{HbA1c}(\%)$ & $5.70 \pm 0.30$ & $5.60 \pm 0.30$ & 0.64 \\
\hline HOMA-IR & $5.63 \pm 3.60$ & $1.74 \pm 0.70$ & $<0.001 * * *$ \\
\hline
\end{tabular}

Statistical significance: ${ }^{*} \mathrm{p}<0.05,{ }^{* *} \mathrm{p}<0.01,{ }^{* * *} \mathrm{p}<0.001$

(Data presented as mean \pm SD, BMI: body mass index, FBG: fasting blood glucose, FI: fasting insulin, HDL-C highdensity lipoprotein, LDL-C low-density lipoprotein, HbA1c: glycosylated haemoglobin, HOMA-IR: homeostasis model assessment-insulin resistance index.)

\section{Discussion}

Preptin is a 34-amino-acid peptide and a proinsulin-like growth factor II derivative (pro-IGF-II) that enhances insulin secretion. It is secreted from pancreatic $\beta$ cells. The results of previous studies in rats demonstrate that preptin promotes insulin secretion in the second phase in a concentration-dependent manner. Preptin was reported to increase insulin secretion physiologically in the presence of a maximally stimulating concentration of glucose. ${ }^{3}$

Bu et al. reported that preptin levels were higher in patients with type 2 Diabetes Mellitus and IGT compared with healthy controls. ${ }^{12}$ On the other hand, 8 years after this study, Yang et al reported that fasting plasma preptin levels were higher in patients with type 2 Diabetes Mellitus compared to patients with IGT and healthy controls. ${ }^{13}$ In both studies, similar results were obtained in preptin levels in type 2 Diabetes Mellitus, but there was no common result in patients with IGT.

To our knowledge this is the first study to evaluate preptin levels in patients with only IR. In addition, subgroup analysis was conducted in patients with IGT. And also different outcomes, which revealed the relationship between IGT and preptin, were reassessed in this study. The relationship between IR, IGT and preptin levels has been researched. First, we divided the samples into IR and control (non-IR but NGT) groups. Patients with IR had significantly higher preptin levels compared with control group. At the same time, there was a positive correlation between the serum preptin levels and HOMA-IR and fasting insulin levels. Based on previous similar results, it can be assumed that preptin plays an important role in the pathogenesis of IR. Sub-group analysis was then performed and patients with IR were divided into two groups, with IGT and with NGT, and reevaluated. There were no statistically significant differences in preptin levels between these two groups. 
Table 2. Clinical characteristics and preptin levels of subgroups (Group 1; patients with normal insulin level and NGT, group 2; patients with IR and NGT, group 3; patients with IR and IGT)

\begin{tabular}{|c|c|c|c|c|c|c|}
\hline & $\begin{array}{c}\text { Group 1 } \\
\text { IR(-), NGT } \\
(\mathrm{n}=37)\end{array}$ & $\begin{array}{c}\text { Group 2 } \\
\text { IR(+), NGT } \\
(\mathrm{n}=23)\end{array}$ & $\begin{array}{c}\text { Group } 3 \\
\text { IR(+), IGT } \\
(\mathrm{n}=26)\end{array}$ & $\begin{array}{c}\text { Group } \\
1-2\end{array}$ & $\begin{array}{c}\text { Group } \\
1-3\end{array}$ & $\begin{array}{c}\text { Group } \\
2-3\end{array}$ \\
\hline $\begin{array}{l}\text { Preptin } \\
\text { (pg/mL) }\end{array}$ & $32.68 \pm 26.86$ & $62.41 \pm 73.62$ & $98.68 \pm 65.88$ & $0.064^{\mathrm{a}}$ & $<0.001{ }^{d}$ & 0.018 \\
\hline Age(years) & $43.53 \pm 12.17$ & $40.83 \pm 11.74$ & $46.77 \pm 9.02$ & 0.164 & $<0.001$ & 0.092 \\
\hline BMI $\left(\mathrm{kg} / \mathrm{m}^{2}\right)$ & $28.48 \pm 6.10$ & $32.84 \pm 4.51$ & $32.80 \pm 4.48$ & 0.002 & 0.002 & 0.992 \\
\hline Insulin(uU/mL & $7.56 \pm 2.62$ & $22.29 \pm 8.26$ & $24.16 \pm 16.45$ & $<0.001^{\mathrm{c}}$ & $<0.001^{\mathrm{e}}$ & 0.471 \\
\hline HOMA-IR & $1.6 \pm 0.51$ & $4.9 \pm 1.96$ & $6.54 \pm 4.54$ & $<0.001^{b}$ & $0.001^{f}$ & 0.149 \\
\hline FBG $(\mathrm{mg} / \mathrm{dL})$ & $87.34 \pm 8.53$ & $88.73 \pm 6.22$ & $109.58 \pm 8.10$ & 0.573 & $<0.001$ & $<0.001$ \\
\hline HbA1c(\%) & $5.64 \pm 0.37$ & $5.66 \pm 0.42$ & $5.8 \pm 0.37$ & 0.708 & 0.060 & 0.153 \\
\hline $\mathrm{TC}(\mathrm{mg} / \mathrm{dL})$ & $192.59 \pm 44$ & $188.73 \pm 41.48$ & $198.23 \pm 44.24$ & 0.591 & 0.884 & 0.516 \\
\hline TG (mg/dL) & $119.86 \pm 63.97$ & $158.78 \pm 110.97$ & $181.26 \pm 113.72$ & 0.137 & 0.034 & 0.714 \\
\hline $\begin{array}{l}\text { HDL- } \\
\mathrm{C}(\mathrm{mg} / \mathrm{dL})\end{array}$ & $50.05 \pm 10.48$ & $43.13 \pm 7.512$ & $43.19 \pm 12.29$ & 0.109 & 0.501 & 0.051 \\
\hline $\begin{array}{l}\text { LDL- } \\
\text { C(mg/dL) }\end{array}$ & $116.72 \pm 44.41$ & $118.56 \pm 37.80$ & $119.07 \pm 37.21$ & 0.851 & 0.217 & 0.252 \\
\hline Urea(mg/dL) & $22.62 \pm 7.12$ & $26.30 \pm 5.67$ & $24.76 \pm 7.56$ & 0.338 & 0.594 & 0.142 \\
\hline $\begin{array}{l}\text { Creatinin(mg/d } \\
\text { L) }\end{array}$ & $0.70 \pm 0.19$ & $0.76 \pm 0.18$ & $0.76 \pm 0.16$ & 0.950 & 0.825 & 0.770 \\
\hline
\end{tabular}

(Data presented as mean \pm SD. NGT normal glucose tolerance, IGT impaired glucose tolerance, BMI body mass index, TC total cholesterol, TG triglyceride, HDL high-density lipoprotein, LDL low-density lipoprotein, FBG fasting blood glucose, HbA1c glycosylated hemoglobin, HOMA-IR homeostasis model assessment-insulin resistance index.)

a P < 0.05 IR patients with NGT, compared with IR (-) patients with NGT

b P $<0.05$ IR patients with NGT, compared with IR (-) patients with NGT

c P $<0.05$ IR patients with NGT, compared with IR (-) patients with NGT

d P $<0.05$ IR patients with IGT, compared with IR (-) patients with NGT

e $\mathrm{P}<0.01$ IR patients with IGT, compared with IR $(-)$ patients with NGT

f $\mathrm{P}<0.01$ IR patients with IGT, compared with IR (-) patients with NGT

Table 3. Relationship between HOMA-IR, insulin, BMI and preptin levels in patients with IR

\begin{tabular}{|l|c|c|}
\hline & \multicolumn{2}{|c|}{ Patient group } \\
\hline Preptin and HOMA-IR & rho & p \\
\hline Preptin and insulin & 0.43 & $0.006^{* *}$ \\
\hline Preptin and BMI & 0.64 & $0.001^{* * *}$ \\
\hline Preptin and triglycerid & 0.41 & $0.003^{* *}$ \\
\hline
\end{tabular}

Statistical significance: ${ }^{*} \mathrm{p}<0.05,{ }^{* *} \mathrm{p}<0.01,{ }^{* * *} \mathrm{p}<0.001$

(HOMA-IR: homeostasis model assessment of insulin resistance, BMI: body-mass index)

That is, although the preptin level was elevated in patients with IR, the change in fasting blood sugar did not affect the preptin level. In patients with IR, the mechanism secreting the insulin is also thought to secrete the preptin. It means that the increased preptin level in these patients is not the cause, it is the response. Because there is no correlation between glucose tolerance and 
preptin in IR patients. In other words, it can be said that the insulin secretory mechanism is directly proportional to the preptin rather than the blood sugar change. Although, there are some studies that promote there is a direct proportionate relationship between preptin levels and fasting blood sugar, our findings are similar to the study of Yang et al. ${ }^{13}$ Buchanan et al reported that at low micromolar concentrations, preptin (and analogues) acts to stimulate insulin secretion in both the presence and absence of glucose. ${ }^{8}$ Although the association between preptin and type 2 Diabetes Mellitus has been proven by previous studies, it can be concluded that fasting plasma preptin levels are independent of plasma glucose level.

Elevated preptin level in patients with type 2 Diabetes Mellitus might be the result of drug use, increased secretion and/or decreased preptin metabolism. ${ }^{13}$ It can be said that increased preptin levels in type 2 Diabetes Mellitus is related to increased insulin levels independently of blood glucose.

Furthermore, we found that plasma preptin level was positively correlated with BMI, HOMA-IR and fasting insulin level. Bu et al reported that in the patients with Polycystic ovary syndrome (PCOS) plasma preptin was positively correlated with HOMA-IR, but not with fasting insulin. The relationship between PCOS and IR is known, but because of other hormonal disorders in PCOS it can be thought that there is no relationship between fasting insulin and preptin.

There was no significant difference in age, BMI, fasting glucose, total cholesterol, HDL-C, LDL$\mathrm{C}$, urea, creatinine and $\mathrm{HbA} 1 \mathrm{c}$ levels between the IR patients and the control group in our study. However, preptin and triglyceride levels were significantly higher in patients with IR. Similar to previous studies with type 2 Diabetes Mellitus patients, it has been revealed that triglyceride (TG) and preptin levels are independently related to each other. ${ }^{13}$ These results reveals that there is a potential relationship between preptin and glucose-lipid metabolism.

Some limitations of our study need to be considered. First limitation of the current study is the relatively small sample size. With a wider patient population, more reliable results can be obtained. Our analyses are based on single measurements of blood preptin, which may not reflect the relationship over time. In conclusion, our results of elevated plasma preptin levels in IR patients suggested that preptin may play a role in the pathogenesis of IR However, this needs to be clarified in further studies.

\section{Conflict of Interest}

The authors declare that there is no conflict of interests regarding the publication of this paper.

\section{References}

1. Lin D, Chun TH, Kang L. Adipose extracellular matrix remodeling in obesity and insulin resistance. Biochem Pharmacol. 2016;119:8-16.

2. Kahn BB, Flier JS. Obesity and insulin resistance. J Clin Invest. 2000;106(4):473-81.

3. Buchanan CM, Phillips AR, Cooper GJ. Preptin derived from proinsulin-like growth factor II (proIGF-II) is secreted from pancreatic islet beta-cells and enhances insulin secretion. Biochem J 2001;360(2):431-9.

4. Cooper G, Willis A, Clark A, Turner R, Sim R and Reid K. Purification and characterization of a peptide from amyloid-rich pancreases of type 2 diabetic patients . Proc. Natl. Acad. Sci. U.S.A. 1997;84(23):8628-32.

5. Tatemoto K, Efendic S, Mutt V, Makk G, Feitner G and Barachas J. Pancreastatin, a novel pancreatic peptide that inhibits insulin secretion. Nature (London)1986;324(6096): 476-8.

6. Hutton JC, Peshavaria M, Johnston CF, Ravazzola M, Orci L. Immunolocalization of betagranin: a Chromogranin A-related protein of the pancreatic B-cell. Endocrinology. 1988;122(3):1014-20. 
7. Lewitt MS, Dent MS, Hall K. The insulin-like growth factor system in obesity, insulin resistance and type 2 diabetes mellitus. J Clin Med. 2014;3(4):1561-74.

8. Buchanan CM, Peng Z, Cefre A. Preptin analogues: chemical synthesis, secondary structure and biological studies. Chem Biol Drug Des 2013;82(4):429-37.

9. Aydin S. Three new players in energy regulation: Preptin, adropin and irisin. Peptides. 2014;56:94110.

10. Canoy D, Buchan I. Challenges in obesity epidemiology. Obesity reviews. 2007;8(supplement 1):1-11

11. World Health Organization(internet). https://www.who.int/diabetes/publications/diagnosis_diabetes2006/en//IDF Consultation. Geneva: World Health Organization; 2006.(Accessed:15.01.2019)

12. Bu Z, Kuok K, Meng J, Wang R, Xu B. The relationship between polycystic ovary syndrome, glucose tolerance status and serum preptin levels. Reprod Biol Endocrinol 2012;10(1):10.

13. Yang G, Li L, Chen W. Ann Med Circulating preptin levels in normal, impaired glucose tolerance, and type 2 diabetic subjects. 2009;41(1):52-6. 